\title{
Ethanolamine Kinase 1
}

National Cancer Institute

\section{Source}

National Cancer Institute. Ethanolamine Kinase 1. NCI Thesaurus. Code C122825.

Ethanolamine kinase 1 (452 aa, $~ 51 \mathrm{kDa}$ ) is encoded by the human ETNK1 gene. This protein plays a role in lipid phosphorylation. 